\title{
Instruction Using Social Media in Global Higher Education
}

\author{
Robert E. Waller ${ }^{1}$, Pamela A. Lemoine ${ }^{2} \&$ Michael D. Richardson ${ }^{1}$ \\ ${ }^{1}$ Educational Leadership, Columbus State University, Columbus, USA \\ ${ }^{2}$ Educational Leadership, Troy University, Phenix City, USA \\ Correspondence: Michael D. Richardson, Professor of Educational Leadership, Columbus State University, 4225 \\ University Drive, Columbus, GA 31907, USA. Tel: 706-325-0612.
}

Received: April 3, 2019

Accepted: April 19, 2019

Online Published: April 20, 2019

doi:10.20849/jed.v3i1.563

URL: https://doi.org/10.20849/jed.v3i1.563

\begin{abstract}
The technological revolution of the past two decades has changed communication, higher education, and the global society. As a result, there exists a wide gulf between the unlimited use of technology and higher education, particularly with respect to digital communications between professors and students. Web 2.0 digital technologies convey information in a different manner than before and allow for interaction with distance participants. Personal use of digital technologies for social media communication is one thing; social media use by professors for communication with students is another. Both aspects should be examined in detail to determine the future directions for global learning.
\end{abstract}

Keywords: global higher education, social media, teaching in global higher education, digital technology, privacy issues and globalization

\section{Introduction}

Social media has become a catalyst for $21^{\text {st }}$ century global higher education both as an administrative tool and an instrument for instruction (Aueretsch, Lehmann, \& Wright, 2014; Greenhow, 2011). The use of social media in a classroom setting provides equitable access to multimedia learning tools that address inclusiveness: from special needs students to acceleration of learning for more capable students (Huda, Luthfi, Jasmi, Basiron, Mustari, Safar, Embong, Mohamad, \& Mohamed, 2019). Social media technology is rapidly becoming an integral part of the typical operation of higher education institutions, particularly those competing in the global marketplace (Mok, 2015; Quershi \& Nair, 2015). The use of social media for instructional purposes in global higher education is becoming a topic for increased discussion to ascertain the educational and ethical issues for resolution. Some would argue that the use of social media in global higher education has been accelerated by the rise of globalization and the need for improved communication globally (Mense, Garretson, Lemoine, \& Richardson, 2018; Piven, Gandell, Lee, \& Simpson, 2018).

\section{Social Media}

Social media and social networking sites provide interactive communication through Internet web sites, forums, weblogs (blogs), microblogs, wikis, social media networks, podcasts, discussion forums, photo sharing sites, and video sites (Higdon \& Topaz, 2009; Junco, 2011; Salmon, 2005; Shih \& Waugh, 2011; Yu, Tian, Vogel, \& Kwok, 2010). Social media sites provide connections enabling users to link to others, to send messages, to link to social networking sites permitting users to connect with friends and colleagues, to send mails and instant messages, to blog, to meet new people, to share pictures and information on common interests and to post personal information profiles (Junco, Heibergert, \& Loken, 2010).

Social networks permit participants to publish personal information and to communicate with friends, make new friends and share contents such as photos and videos (Ellison, Steinfield, \& Lampe, 2007). The uses of social networks have increased exponentially in recent years although there is some controversy over the use of these systems (Au \& Lam, 2015). Many perceive that only younger persons use the Internet and social media but use of social media by older adults has increased dramatically (Subrahmanyam, Reich, Waechter, \& Espinoza, 2008). Higher education professors envision the use of Web 2.0 technologies as a solution to help transform higher education and dramatically improve student learning (Jones \& Skinner, 2014) but the use of social media by university professors also stimulates challenges addressing issues of student safety and privacy of student and instructor information and data (Lemoine, Hackett, \& Richardson, 2017c). 


\section{Instruction Using Social Media}

Online and global higher education venues expand daily (Kumar \& Nanda, 2019). Some researchers have suggested that students using online learning resources outperform students in traditional face-to-face teaching settings and that social media expands opportunities for learning (Allen \& Seaman, 2010). They have also demonstrated that online learning experiences more clearly meet individual student learning needs (Keengwe, Kidd, \& Kyei-Blankson, 2009; Stewart \& Lanzillo, 2018). With the requirement that $21^{\text {st }}$ century student skills include using information effectively, social media provides global higher education educators access to different methods for teaching and learning in the online and face-to-face environments (Dede, 2011; Gandell \& Piven, 2018). The challenge for professors is to move beyond traditional teaching methods and provide students with social media skills and strategies in order to safely take charge of their own learning in the global environment (MccLoughlin \& Lee; 2010).

Social media provides a real time method to have a conversation between two or more people which is critical to the success of global higher education. Social media formats include online platforms, which provide news updates, as well as information personalized for the interests of social media subscribers (Wiid, Cant, \& Nell, 2013). Teaching and communication formats for professors and students once confined to print and then email communications are now methods to share information through social media tools such as Facebook, Flickr, Twitter, LinkedIn, Google+, YouTube, and other emerging public platforms (Jones, Ramanau, Cross \& Healing, 2010; Henderson, Selwyn, \& Aston, 2017; Miranda, Isaias, \& Pifano, 2016). Universities are using social media platforms to share their missions, market, and engage in conversations with future and current students, both globally and locally (Wandel, 2008).

Social media allows professors to expand their messages and listen to what students want (Roebuck, Silva, \& Bell, 2013). Not only is it important that professors communicate to students, but it is important that the students transmit their needs to professors and administrators particularly in the online and global situation (Simpson, 2018b). Access to social media for global higher education instructors has also resulted in a change for higher education delivery systems (Moghavvemi, Paramanathan, Rahin, \& Sharabti, 2017; Navarro \& Shoemaker, 1999). Social media encourages students to become more active participants in their own learning and explore new learning opportunities with students who are different and come from different countries and cultures (Englund, Olofsson, \& Price, 2017). Social media permit students and professors to have instant access to news, information, and interactive experiences through computers, tablets, and smartphones (Hrastinski \& Aghaee, 2012).

Twenty-four/seven access to digital technologies can facilitate new media for professional learning through interactive technology (Flavin, 2016; Lemoine, Hackett, \& Richardson, 2016). The use of social media as educational tools presents professors with the possibilities of using technology with students to facilitate access to information for research, creativity and collaboration (Gonzalez, Gasco, \& Llopis, 2016; Kivunia, 2015; Lodge \& Bonsanquet, 2014). However, adding social media tools to instruction requires professors to restructure $20^{\text {th }}$ century pedagogies to leverage $21^{\text {st }}$ century opportunities for learning especially in the global context (Lubua, Semlambo, \& Pretorius, 2017). For professors and students, once isolated to their own individual classrooms with limited opportunities beyond the classroom, social media promotes access, communication, tools for collaboration and analysis, and the ability to interactively share their learning and knowledge among a vast audience when responding globally (Pimmer, Mateescu, \& Grohbiel, 2016).

\section{Ethical, Practical and Educational Concerns of Social Media Use}

Students are using social media tools both inside and outside the classroom because social media tools provide great opportunities to connect and learn from and with others in a global milieu (Rashid \& Asghar, 2016). Social networking among professors and students also suggests the perceived intimacy of technology and the perception that there is nothing wrong with the use of social networking for whatever reason (Simpson, 2018a). Professors should help to educate users of technology that there is an abundance of materials available on the web, but few guarantees of the quality of the materials (Dee, 2016; Feigenbaum \& Iquani, 2015). So, if students search the Internet for information, they should understand the lack of quality controls for materials found on the Internet (Lemoine \& Richardson, 2013).

While the use of social media is a popular method for communication among students, some social media tools in universities are blocked and filtered usually due to concerns with cyberbullying and other inappropriate uses of social media (Nelson, Simek, \& Foltin (2009-10). Barton and Ryan (2014) suggest part of the responsibilities for professors is to teach the responsible use of social media along with other areas for which they are responsible. It is the responsibility of the professor to speak openly to students and to train them to make ethical 
decisions about social networking, to become digitally literate (Chawinga, 2017; Tess, 2013). Some universities have taken a proactive stance in the use of social media in classrooms. Addressed as professional social media use, university social media guidelines often detail recommended practices for communication between employees, as well as between employees and students (Fenwick \& Edwards, 2016; Mora, Pont, Casado, \& Iglesias, 2015).

Professors are expected to review university guidelines for social media use "in order to maintain a professional and appropriate relationship with students" (Dede, 2011, p. 4). To establish effective instruction that uses social media, professors must listen and learn from current conversations with students, participate in the use of social media to promote positive learning, and become familiar with students' needs (Abdelraheem \& Ahmed, 2015; Fogel \& Nehmad, 2009; Manca \& Ranieri, 2016; Thomas, Johnson, \& Fishman, 2018).

\section{Challenges of Social Media Use in Global Higher Education}

Technology has outgrown use for only administrative applications in global higher education institutions (Boyd \& Ellison, 2007). However, there appears to be very little consensus as to how to address the issues raised by social networking (Al-Emran, Elsherif, \& Shaalan, 2016). Global universities have concerns with student access to social media technologies as well as the provision of devices and technological infrastructure supporting the use of technology for both professors and students (Anderson \& Dron, 2011; Conner \& Rabovsky, 2011; Hemmi, Bayne, \& Land, 2009; Selwyn, 2016).

Persuading some global universities to allow educational access to social media tools has been an issue in many countries (Lemoine, Hackett, \& Richardson, 2017b). Educators and researchers support the need to provide for the appropriate use of technology in classrooms (Bugawa \& Mirzal, 2018; Chernikova \& Varonis, 2016), but some global university faculty members are reluctant to use social media when it is not a familiar tool or if they are hesitant to try new learning approaches (Bernard, Borokhovski, Schmid, Tamim, \& Abrami, 2014). Professors must become skilled in the technology as well as the pedagogy for using social media. Training for professors is needed to ensure that they can use mobile learning technologies for both a global and local audience of students (Hemmi, Bayne, \& Land, 2009; Dumpit \& Fernandez, 2017).

Additionally, administrators and professors need to be well versed in current technologies for both professional and student use (Galloway, Curtis, \& Arora, 2018). Some global universities and colleges have done nothing; some have very specific rules about what digital and communication technology is permitted and how and when it can be used (Sobaih, Moustafa, Ghandforush, \& Khan, 2016). Other institutions have some variation of the two extremes. Some global higher education institutions are particularly attuned to social networking and provide detailed guidelines and rules while others are oblivious to the dangers of teachers and students using social networks or the Internet (Jang, 2015; McDermott \& Kowalsky, 2011; Nelson, Simek \& Foltin, 2009-10). Specifically, professors must be vigilant monitors when using social media for coursework with students. However, university and university employees governed by principles of free speech and academic freedom still face risks (Castagnera \& Lanza, 2010; Fogel \& Nehmad, 2009; Manea \& Ranieri, 2016; Thomas, Johnson, \& Fishman, 2018).

Social media use reduces boundaries between university faculty and students and audiences with access to open social media platforms (Ngai, Moon, Lam, Chin, \& Tao, 2015; Sleeman, Lang, \& Lemon, 2016) however, privacy issues with social media mean faculty must decide if the use of social media presents inappropriate risks that can become controversial and challenging (Castagnera \& Lanza, 2010; Manea \& Ranieri, 2016). Legal and ethical issues abound with social media and there are few defining laws that provide regulations and guidance for professors and social media use particularly in global institutions (Nelson, Simek, \& Foltin, 2009-10). Social media platforms, the Internet, tablets, and smart phones provide new technologies that have not been addressed in updated legislation (Allen \& Seaman, 2010). Social media connections between professors and students also blur the lines of relationships (Ophus \& Abbitt, 2009).

With social media access to forums such as Facebook, both professors and students can see information, profiles, pictures, and communications about one another bringing about issues with professionalism (Shelton, 2016). Many global universities are addressing social media use by employees by drawing up university policies regarding the use of cyberlearning technologies, ethics, and employee and student conduct (Benson \& Morgan, 2018). Guidelines cover issues with confidentiality of student and teacher data and personal information, use for academic coursework, and cyber security policies (Corcoran \& Duane, 2019). While employees are encouraged to showcase college and university programs through platforms such as Facebook, university guidelines for social media use need to cover lewd and indecent and inappropriate conduct, threats, disruption of university 
programs, and intentional use of malicious or defamatory or hateful materials (Au \& Lam, 2015; Bickerstaff \& Cormier, 2015).

In a closely related area, professors are now becoming the subject of dismissals and court cases if they have used social media to post information of a personal nature, which is being interpreted as affecting their ability to teach students (Ophus \& Abbitt, 2009). Professors have been asked to resign over comments regarding sexual performance, gender preference, and photos with alcoholic beverages. Undoubtedly, there will be court cases to determine the right of privacy for professors as individuals as compared to their professional responsibilities but in a global environment each country will assign rules and regulations for employee conduct (Castagnera \& Lanza, 2010).

\section{Concluding Thoughts}

During the past 15 years methods for communicating and sharing have changed drastically, many would argue that the change is a result of globalization (Chan, Mense, Crain-Dorough, Richardson, \& Lane, 2013). In the current environment, global higher education students use digital media for communication and sharing information at an increasing rate (Bartosik-Purgat, Filimon, \& Kiygi-Calli, 2017; Zhu, 2015). Additionally, the focus on learning with digital media or cyberlearning is expected to escalate as more higher education institutions go global (Coates, Kelly, \& Naylorm 2017; Zhao, 2015).

Cyberlearning has become a trend that includes both independent learning and learning in collaboration with others (Greenhow, 2011; Lemoine \& Richardson, 2013). This flexibility is dependent on learning needs, motivations and contexts where students can use mobile devices for personalized learning anytime and anywhere (Balakrishnan \& Gan, 2016). Social media and mobile technologies provide multiple options of services that are satisfying different professor and student needs in terms of flexibility, fluidity, multitasking and accelerated means of learning (Li \& Zhao, 2015). Moreover, social media and mobile technologies have enabled students to have better control over what they do, how they do it, and when they do it which has resulted in better student and faculty engagement with learning activities (Gikas \& Grant, 2013; Piotrowski, 2015).

Student privacy is a primary concern; thus, names of students, pictures, and personal information about students should not be allowed when students use online resources (Fogel \& Nehmad, 2009; Hemmi, Bayne, \& Land, 2009). Some universities also restrict direct communication between professors and students on personal media sites. Student access to social media also has to be bounded by concerns for privacy and protection for students (Fogel \& Nehmad, 2009).

Professors must provide training for students in digital global citizenship, building knowledge and responsibility for safe technology usage (Lai \& Kong, 2015; Lemoine, Hackett, \& Richardson, 2017a). Social media is not a "one size fits all" learning technology, it can take many forms: professors conducting independent research, sending e-mails, text messages, or using the camera to record classroom proceedings but with proper use can accentuate learning for students in global universities (Joo, Joung, \& Kim, 2015; Richardson, Brinson, \& Lemoine, 2018).

\section{Conclusions}

The use of social networking and other forms of technology illustrate the global reach of wireless technology for everyone, but it is especially critical for those teaching and learning in today's fluid global higher education environment. The increasing use of social networking in global colleges and universities and in daily use demonstrates the generational shift that is now impacting global higher education institutions.

The use of social media may not be a panacea, but it is a technique that can change learning in global higher education institutions for local and global students. Professors and administrators are challenged to use social media as one technique for increasing cyberlearning and to collaboratively ensure the best learning opportunities for $21^{\text {st }}$ century global students. Social media has some built in concerns but can be used effectively when coupled with professional development for professors who incorporate cyberlearning into their classrooms. Cyberlearning is the key to current and future learning but social media is the force driving the innovation.

\section{References}

Abdelraheem, A. Y., \& Ahmed, A. M. (2015). Electronic social media in teaching: Usages, benefits, and barriers as viewed by Sudanese faculty members. American International Journal of Social Science, 4(5), 58-68.

Al-Emran, M., Elsherif, H. M., \& Shaalan, K. (2016). Investigating attitudes towards the use of mobile learning in higher education. Computers in Human Behavior, 56, 93-102. https://doi.org/10.1016/j.chb.2015.11.033 
Allen, E., \& Seaman, J. (2010). Class differences: Online education in the United States, 2010. Retrieved from http://sloanconsortium.org/publications/survey/class_differences

Anderson, T., \& Dron, J. (2011). Three generations of distance education pedagogy. International Review of Research on Distance and Open Learning, 12(3), 80-97. https://doi.org/10.19173/irrodl.v12i3.890

$\mathrm{Au}$, M., \& Lam, J. (2015). Social media education: Barriers and critical issues. In Technology in education: Transforming educational practices with technology (pp. 199-205). Berlin: Springer. https://doi.org/10.1007/978-3-662-46158-7_20

Audretsch, D. B., Lehmann, E. E., \& Wright, M. (2014). Technology transfer in a global economy. The Journal of Technology Transfer, 39(3), 301-312. https://doi.org/10.1007/s10961-012-9283-6

Balakrishnan, V., \& Gan, C. L. (2016). Students' learning styles and their effects on the use of social media technology for learning. Telematics and Informatics, 33(3), 808-821. https://doi.org/10.1016/j.tele.2015.12.004

Barton, G., \& Ryan, M. (2014). Multimodal approaches to reflective teaching and assessment in higher education. Higher Education Research \& Development, 33(3), 409-424. https://doi.org/10.1080/07294360.2013.841650

Bartosik-Purgat, M., Filimon, N., \& Kiygi-Calli, M. (2017). Social media and higher education: An international perspective. Economics and Sociology, 10(1), 181-191. https://doi.org/10.14254/2071-789X.2017/10-1/13

Bayne S. (2008). Higher education as a visual practice: Seeing through the virtual learning environment. Teaching in Higher Education, 13, 383-394. https://doi.org/10.1080/13562510802169665

Benson, V., \& Morgan, S. (2018). Measuring the social impact: How social media affects higher education institutions. In Social media marketing: Breakthroughs in research and practice (pp. 1167-1184). Hershey, PA: IGI Global. https://doi.org/10.4018/978-1-5225-5637-4.ch055

Bernard, R. M., Borokhovski, E., Schmid, R. F., Tamim, R. M., \& Abrami, P. C. (2014). A meta-analysis of blended learning and technology use in higher education: From the general to the applied. Journal of Computing in Higher Education, 26(1), 87-122. https://doi.org/10.1007/s12528-013-9077-3

Bickerstaff, S., \& Cormier, M. S. (2015). Examining faculty questions to facilitate instructional improvement in higher education. Studies in Educational Evaluation, 46, 74-80. https://doi.org/10.1016/j.stueduc.2014.11.004

Bugawa, A. M., \& Mirzal, A. (2018). The impact of Web 2.0 technologies on the learning experience of students in higher education: A review. International Journal of Web-Based Learning and Teaching Technologies, 13(3), 1-17. https://doi.org/10.4018/IJWLTT.2018070101

Castagnera, J. O., \& Lanza IV, J. (2010). Social networking and faculty discipline: A Pennsylvania case points toward confrontational times, requiring collective bargaining attention. Journal of Collective Bargaining in the Academy, 2(5).

Chan, T. C., Mense, E. G., Crain-Dorough, M., Richardson, M. D., \& Lane, K. E. (2013). Observations through a keyhole: The changing dimension of global higher education. In S. Mukerji, \& P. Tripathi (Eds.), Handbook of research on transnational higher education management (pp. 59-78). Hershey, PA. IGI. https://doi.org/10.4018/978-1-4666-4458-8.ch004

Chawinga, W. D. (2017). Taking social media to a university classroom: Teaching and learning using Twitter and blogs. International Journal of Educational Technology in Higher Education, 14(1), 3.

Chernikova, I. A., \& Varonis, E. M. (2016). Designing and delivering online curriculum in higher education: Riding the perfect storm. The International Journal of Information and Learning Technology, 33(3), 132-141. https://doi.org/10.1108/IJILT-09-2015-0026

Coates, H., Kelly, P., \& Naylor, R. (2017). Leading online education for student success. International Journal of Chinese Education, 6(1), 105-126. https://doi.org/10.1163/22125868-12340076

Conner, T. W., \& Rabovsky, T.M. (2011). Accountability, affordability, access: A review of the recent trends in higher education policy research. Policy Studies Journal, 39(1), 93-112. https://doi.org/10.1111/j.1541-0072.2010.00389_7.x 
Corcoran, N., \& Duane, A. (2019). Organizational knowledge sharing and enterprise social networks: A higher education context. In Educational and social dimensions of digital transformation in organizations (pp. 78-114). Hershey, PA: IGI Global. https://doi.org/10.4018/978-1-5225-6261-0.ch005

Dede, C. (2011). Reconceptualizing technology to meet the necessity of transformation. Journal of Curriculum and Instruction, 5(1), 4-16. https://doi.org/10.3776/joci.2011.v5n1p4-16

Dee, J. R. (2016). Universities, teaching and learning. In L. Leisyte \& U. Wilkesmann (Eds.), Organizing academic work in higher education: Teaching, learning and identities. (pp.13-32). New York, NY: Routledge.

Dumpit, D. Z., \& Fernandez, C. J. (2017). Analysis of the use of social media in higher education institutions (HEIs) using the Technology Acceptance Model. International Journal of Educational Technology in Higher Education, 14(1), 5. https://doi.org/10.1186/s41239-017-0045-2

Ellison, N. B., Steinfield, C., \& Lampe, C. (2007). The benefits of Facebook "friends:" Social capital and college students' use of online social network sites. Journal of Computer-Mediated Communication, 12(4), 1143-1168. https://doi.org/10.1111/j.1083-6101.2007.00367.x

Englund, C., Olofsson, A. D., \& Price, L. (2017). Teaching with technology in higher education: Understanding conceptual change and development in practice. Higher Education Research \& Development, 36(1), 73-87. https://doi.org/10.1080/07294360.2016.1171300

Feigenbaum, A., \& Iqani, M. (2015). Quality after the cuts? Higher education practitioners' accounts of systemic challenges to teaching quality in times of 'austerity'. Journal of Further and Higher Education, 39(1), 46-66. https://doi.org/10.1080/0309877X.2013.778961

Fenwick, T., \& Edwards, R. (2016). Exploring the impact of digital technologies on professional responsibilities and education. European Educational Research Journal, 15(1), 117-131. https://doi.org/10.1177/1474904115608387

Flavin, M. (2016). Technology-enhanced learning and higher education. Oxford Review of Economic Policy, 32(4), 632-645. https://doi.org/10.1093/oxrep/grw028

Fogel, J., \& Nehmad, E. (2009). Internet social network communities: Risk taking, trust and privacy concerns. Computers in Human Behavior, 25(1), 153-160. https://doi.org/10.1016/j.chb.2008.08.006

Galloway, C., Curtis, M., \& Arora, A. S. (2018). Social media driven student-centered learning through social commerce in higher education. In Global business value innovations (pp. 35-45). Cham, Switzerland: Palgrave Pivot. https://doi.org/10.1007/978-3-319-77929-4_3

Gandell, R., \& Piven, I. P. (2018). Using social media in creating and implementing educational practices. In Global perspectives on social media in tertiary learning and teaching: Emerging research and opportunities (pp. 91-117). Hershey, PA: IGI Global. https://doi.org/10.4018/978-1-5225-5826-2.ch005

Gikas, J., \& Grant, M. M. (2013). Mobile computing devices in higher education: Student perspectives on learning with cellphones, smartphones \& social media. The Internet and Higher Education, 19, 18-26. https://doi.org/10.1016/j.iheduc.2013.06.002

González, M. R., Gasco, J., \& Llopis, J. (2016). Facebook and academic performance: A positive outcome. The Anthropologist, 23(1-2), 59-67. https://doi.org/10.1080/09720073.2016.11891924

Greenhow, C. (2011). Online social networking and learning. International Journal of CyberBehavior, Psychology and Learning, 1, 36-50. https://doi.org/10.4018/ijcbpl.2011010104

Hemmi, A., Bayne, S., \& Land, R. (2009). The appropriation and repurposing of social technologies in higher education. Journal of Computer Assisted Learning, 25, 19-30. https://doi.org/10.1111/j.1365-2729.2008.00306.x

Henderson, M., Selwyn, N., \& Aston, R. (2017). What works and why? Student perceptions of 'useful' digital technology in university teaching and learning. Studies in Higher Education, 42(8), 1567-1579. https://doi.org/10.1080/03075079.2015.1007946

Higdon, J., \& Topaz, C. (2009). Blogs and wikis as instructional tools. College Teaching, 57, $105-109$. https://doi.org/10.3200/CTCH.57.2.105-110 
Hrastinski, S., \& Aghaee, N. M. (2012). How are campus students using social media to support their studies? An explorative interview study. Education and Information Technologies, 17(4), 451-464. https://doi.org/10.1007/s10639-011-9169-5

Huda, M., Luthfi, M. J. F., Jasmi, K. A., Basiron, B., Mustari, M. I., Safar, A., ... Mohamed, A. K. (2019). Adaptive online learning technology: Trends in big data era. In Diverse learning opportunities through technology-based curriculum design (pp. 163-195). Hershey, PA: IGI Global. https://doi.org/10.4018/978-1-5225-5519-3.ch008

Jang, Y. (2015). Convenience matters: A qualitative study on the impact of use of social media and collaboration technologies on learning experience and performance in higher education. Education for Information, 31(1, 2), 73-98. https://doi.org/10.3233/EFI-150948

Jones, C., Ramanau, R., Cross, S., \& Healing, G. (2010). Net generation or digital natives: Is there a distinct new generation entering university? Computers and Education, 54(3), $722-732$. https://doi.org/10.1016/j.compedu.2009.09.022

Jones, P., \& Skinner, H. (2014). E-learning globalization: The impact of e-learning-what difference has it made? Education+Training, 56(2-3). https://doi.org/10.1108/ET-11-2013-0128

Joo, Y. J., Joung, S. Y., \& Kim, H. J. (2015). Structural relationships between factors affecting m-learners' course satisfaction and learning persistence. Educational Technology International, 16(2), 85-110.

Junco, R. (2011). The relationship between frequency of Facebook use, participation in Facebook activities, and student engagement. Computers \& Education, 58, 162-71. https://doi.org/10.1016/j.compedu.2011.08.004

Junco, R., Heibergert, G., \& Loken, E. (2010). The effect of Twitter on college student engagement and grades. Journal of Computer Assisted Learning, 27, 119-132. https://doi.org/10.1111/j.1365-2729.2010.00387.x

Keengwe, J., Kidd, T. T., \& Kyei-Blankson, L. (2009). Faculty and technology: Implications for faculty training and technology leadership. Journal of Science Education and Technology, 18(1), 23-28.

Kivunja, C. (2015). Innovative methodologies for 21 st century learning, teaching and assessment: A convenience sampling investigation into the use of social media technologies in higher education. International Journal of Higher Education, 4(2), 1. https://doi.org/10.5430/ijhe.v4n2p1

Kumar, V., \& Nanda, P. (2019). Social media in higher education: A framework for continuous engagement. International Journal of Information and Communication Technology Education (IJICTE), 15(1), 109-120.

Lai, K. W., \& Hong, K. S. (2015). Technology use and learning characteristics of students in higher education: Do generational differences exist?. British Journal of Educational Technology, 46(4), 725-738.

Lane, K. E., Kehr, G. A., \& Richardson, M. D. (2010). The paradox of productivity measurement in higher education. Academe: Journal of Leadership and Management in Higher Education, 1(3), 23-39.

Lemoine, P. A., Hackett, P. T., \& Richardson, M. D. (2017a). The impact of online learning on global intellectual property issues. In Scholarly communication and the publish or perish pressures of academia (pp. 279-311). Hershey, PA: IGI Global. https://doi.org/10.4018/978-1-5225-1697-2.ch013

Lemoine, P. A., Hackett, P. T., \& Richardson, M. D. (2017b). Global higher education and VUCA-Volatility, uncertainty, complexity, ambiguity. In Handbook of research on administration, policy, and leadership in higher education (pp. 549-568). Hershey, PA: IGI Global.

Lemoine, P. A., Hackett, P. T., \& Richardson, M. D. (2017c). The impact of social media on policy decisions in international higher education. In Handbook of research on administration, policy, and leadership in higher education (pp. 173-199). Hershey, PA: IGI Global. https://doi.org/10.4018/978-1-5225-0672-0.ch009

Lemoine, P. A., Hackett, T., \& Richardson, M. D. (2016). Higher education at a crossroads: Accountability, globalism and technology. In Handbook of research on quality assurance and value management in higher education (pp. 27-57). Hershey, PA: IGI Global. https://doi.org/10.4018/978-1-5225-0024-7.ch002

Lemoine, P., \& Richardson, M. D. (2013). Cyberlearning: The impact on instruction in higher education. Researcher: An Interdisciplinary Journal, 26(3).

Li, M., \& Zhao, Y. (Eds.). (2015). Exploring learning \& teaching in higher education. New York, NY: Springer.

Lodge, J. M., \& Bonsanquet, A. (2014). Evaluating quality learning in higher education: Re-examining the evidence. Quality in Higher Education, 20(1), 3-23. https://doi.org/10.1080/13538322.2013.849787 
Lubua, E. W., Semlambo, A., \& Pretorius, P. D. (2017). Factors affecting the use of social media in the learning process. South African Journal of Information Management, 19(1), 1-7. https://doi.org/10.4102/sajim.v19i1.764

Manca, S., \& Ranieri, M. (2016). Facebook and the others. Potentials and obstacles of social media for teaching in higher education. Computers \& Education, 95, 216-230. https://doi.org/10.1016/j.compedu.2016.01.012

McDermott, E., \& Kowalsky, M. (2011). From teaching to training: Considering the implications of social media from school to the workplace. In Proceedings of World Conference on E-Learning in Corporate, Government, Healthcare, and Higher Education 2011 (pp. 1478-1480). Chesapeake, VA: AACE.

McLoughlin, C., \& Lee, M. J. W. (2010). Personalised and self-regulated learning in the web 2.0 era: International exemplars of innovative pedagogy using social software. Australasian Journal of Educational Technology, 26(1), 28-43. https://doi.org/10.14742/ajet.1100

Mense, E. G., Garretson, C. J., Lemoine, P. A., \& Richardson, M. D. (2018). Global marketing of higher education e-learning. International Journal of Technology and Educational Marketing (IJTEM), 8(2), 59-74. https://doi.org/10.4018/IJTEM.2018070104

Miranda, P., Isaias, P., \& Pífano, S. (2016). Higher education students' perceptions of positive and negative effects of social networking in Portugal. In Social networking and education (pp. 111-127). Cham, Switzerland: Springer. https://doi.org/10.1007/978-3-319-17716-8_8

Moghavvemi, S., Paramanathan, T., Rahin, N. M., \& Sharabati, M. (2017). Student's perceptions towards using e-learning via Facebook. Behaviour \& Information Technology, 36(10), 1081-1100.

Mok, K. H. (2015). Higher education transformations for global competitiveness: Policy responses, social consequences and impact on the academic profession in Asia. Higher Education Policy, 28(1), 1-15.

Mora, H. M., Pont, M. T. S., Casado, G. D. M., \& Iglesias, V. G. (2015). Management of social networks in the educational process. Computers in Human Behavior, 51, 890-895. https://doi.org/10.1016/j.chb.2014.11.010

Navarro, P., \& Shoemaker, J. (1999). The power of cyberlearning: An empirical test. Journal of Computing in Higher Education, 11, 33-46. https://doi.org/10.1007/BF02940841

Nelson, S., Simek, J., \& Foltin, J. (2009-10). The legal implications of social networking. Regent University Law Review, 22(1), 1-34.

Ngai, E. W., Moon, K. L. K., Lam, S. S., Chin, E. S., \& Tao, S. S. (2015). Social media models, technologies, and applications: An academic review and case study. Industrial Management \& Data Systems, 115(5), 769-802. https://doi.org/10.1108/IMDS-03-2015-0075

Ophus, J. D., \& Abbitt, J. T., (2009, December). Exploring the potential perceptions of social networking systems in university courses. MERLOT Journal of Online Learning and Teaching, 5(4), 638-648.

Pimmer, C., Mateescu, M., \& Gröhbiel, U. (2016). Mobile and ubiquitous learning in higher education settings. A systematic review of empirical studies. Computers in Human Behavior, 63, 490-501.

Piotrowski, C. (2015). Academic applications of social media: A review of peer-review research in higher education. Psychology \& Education, 52(3-4), 15-22.

Piven, I., Gandell, R., Lee, M., \& Simpson, A. M. (2018). Global perspectives on social media in tertiary learning and teaching: Emerging research and opportunities. In Advances in educational technologies and instructional design. Hershey, PA: IGI Global. https://doi.org/10.4018/978-1-5225-5826-2

Qureshi, R., \& Nair, S. (2015). The role of higher education in emerging knowledge society. Global Journal on Humanities and Social Sciences, 1(1), 543-548.

Rashid, T., \& Asghar, H. M. (2016). Technology use, self-directed learning, student engagement and academic performance: Examining the interrelations. Computers in Human Behavior, 63, 604-612.

Richardson, M. D., Brinson, S. G., \& Lemoine, P. A. (2018). Using social media to facilitate instruction and increase marketing in global higher education. In Marketing initiatives for sustainable educational development (pp. 226-245). Hershey, PA: IGI Global. https://doi.org/10.4018/978-1-5225-5673-2.ch009

Roebuck, D. B., Siha, S., \& Bell, R. L. (2013). Faculty usage of social media and mobile devices: Analysis of advantages and concerns. Interdisciplinary Journal of E-Learning and Learning Objects, 9, 171-192. 
Salmon, G. (2005). Flying not flapping: A strategic framework for e-learning and pedagogical innovation in higher education institutions. Journal of the Association for Learning Technology, 13(3), 201-218.

Selwyn, N. (2016). Digital downsides: Exploring university students' negative engagements with digital technology. Teaching in Higher Education, 21(8), 1006-1021.

Shelton, C. (2016). Giving up technology and social media: Why university lecturers stop using technology in teaching. Technology, Pedagogy and Education, 26(3), 303-321.

Shih, C., \& Waugh, M. (2011). Web 2.0 Tools for learning in higher education: The presence of blogs, wikis, podcasts, microblogs, Facebook and Ning. In M. Koehler \& P. Mishra (Eds.), Proceedings of Society for Information Technology \& Teacher Education International Conference 2011 (pp. 3345-3352). Chesapeake, VA: AACE.

Simpson, A. M. (2018a). Future directions: Emergent social media technologies and the potential for higher education. In Global perspectives on social media in tertiary learning and teaching: Emerging research and opportunities (pp. 118-135). Hershey, PA: IGI Global. https://doi.org/10.4018/978-1-5225-5826-2.ch006

Simpson, A. M. (2018b). Social media in tertiary education: Considerations and potential issues. In Global perspectives on social media in tertiary learning and teaching: Emerging research and opportunities (pp. 1-19). Hershey, PA: IGI Global. https://doi.org/10.4018/978-1-5225-5826-2.ch001

Sleeman, J., Lang, C., \& Lemon, N. (2016). Social media challenges and affordances for international students: Bridges, boundaries, and hybrid spaces. Journal of Studies in International Education, 20(5), 391-415.

Sobaih, A. E. E., Moustafa, M. A., Ghandforoush, P., \& Khan, M. (2016). To use or not to use? Social media in higher education in developing countries. Computers in Human Behavior, 58, 296-305.

Stewart, M. C., \& Lanzillo, J. D. (2018). An interdisciplinary perspective of incorporating social media into teaching practice. International Journal of Digital Literacy and Digital Competence (IJDLDC), 9(2), 50-61. https://doi.org/10.4018/IJDLDC.2018040104

Subrahmanyam, K., Reich, S. M., Waechter, N., \& Espinoza, G. (2008). Online and offline social networks: Use of social networking sites by emerging adults. Journal of Applied Developmental Psychology, 29(6), 420-433. https://doi.org/10.1016/j.appdev.2008.07.003

Tess, P. A. (2013). The role of social media in higher education classes (real and virtual)-A literature review. Computers in Human Behavior, 29(5), A60-A68. https://doi.org/10.1016/j.chb.2012.12.032

Thomas, R. B., Johnson, P. T., \& Fishman, E. K. (2018). Social media for global education: Pearls and pitfalls of using Facebook, Twitter, and Instagram. Journal of the American College of Radiology. College of Radiology. https://doi.org/10.1016/j.jacr.2018.01.039

Wandel, T. (2008). Colleges and universities want to be your friend: Communicating via online social networking. Planning for Higher Education, 37(1), 35-48.

Wiid, J., Cant, M. C., \& Nell, C. (2013). Open distance learning students' Perception of the use of social media networking systems as an educational tool. The International Business \& Economics Research Journal (Online), 12(8), 867. https://doi.org/10.19030/iber.v12i8.7985

Yu, A. Y., Tian, S. W., Vogel, D., \& Kwok, R. C. (2010). Can learning be virtually boosted? An investigation of online social networking impacts. Computers \& Education, 55, 1494-1503. https://doi.org/10.1016/j.compedu.2010.06.015

Zhao, Y. (2015). A world at risk: An imperative for a paradigm shift to cultivate 21st Century learners. Society, 52(2), 129-135. https://doi.org/10.1007/s12115-015-9872-8

Zhu, C. (2015). Organisational culture and technology-enhanced innovation in higher education. Technology, Pedagogy and Education, 24(1), 65-79. https://doi.org/10.1080/1475939X.2013.822414

\section{Copyrights}

Copyright for this article is retained by the author(s), with first publication rights granted to the journal.

This is an open-access article distributed under the terms and conditions of the Creative Commons Attribution license (http://creativecommons.org/licenses/by/4.0/). 